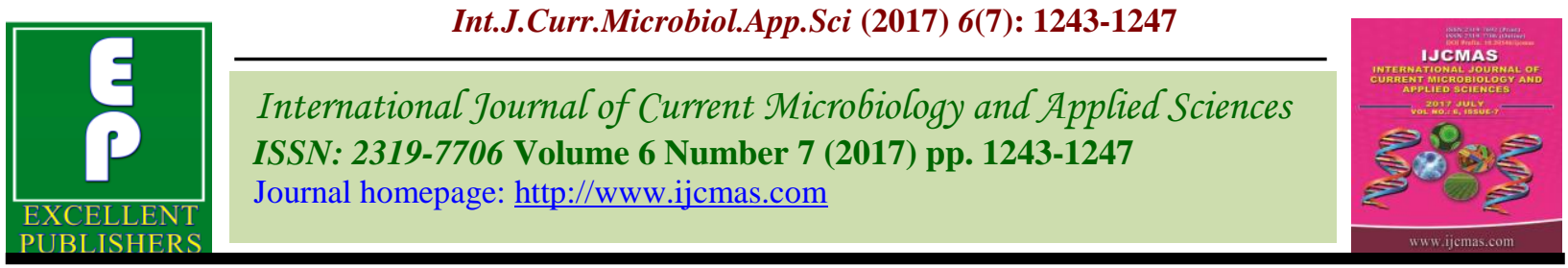

Review Article

https://doi.org/10.20546/ijcmas.2017.607.150

\title{
A Critical Review on Effect of Plant Growth Regulators on Root Vegetables
}

\author{
G. Koteswara Rao*, M. Surendra Babu, M.M. Nagaraju, \\ T. Thomson, G. Ranganna and M. Siva \\ Department of Vegetable Science, College of Horticulture, Dr. YSRHU, A.P., India \\ *Corresponding author
}

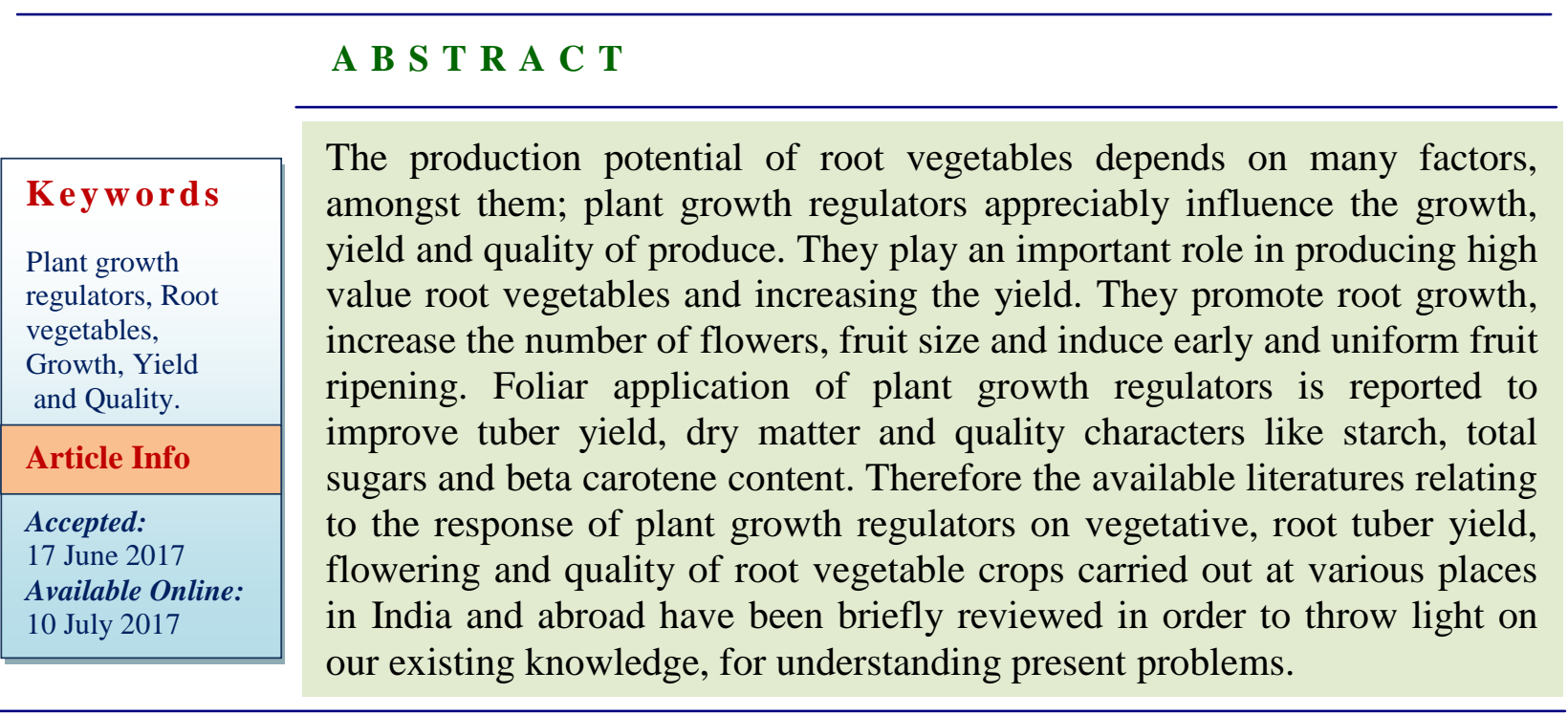

\section{Introduction}

Root vegetables especially cassava, sweet potato, elephant foot yam, taro, tannia, yams, yam bean, arrow root, onion, carrot, radish etc. still continue to be major crops contributing significantly to human and animal food apart from finding use in various industrial applications. Provide their vital roots and stems for cooking delicious foods. They are wellknown for their starchy storage usually harvested from below the ground. They have golden history of their role they played in the diet of early human being, especially of our ancestors and saints who used to live in forests. Today also, they constitute a major component of indigenous food, especially for people living in tribal areas in India. These crops are adapted to broad agro-ecological conditions and yield reasonably well even under marginal environments. Root vegetable crops fit well into a variety of cropping systems and can be profitably intercropped in coconut based cropping system.

Besides, good agronomic practices like growing high yielding varieties, providing proper spacing, irrigation, use of fertilizers, optimum sowing time and some advanced crop improvement techniques like application of plant growth substances and appropriate plant protection measures ought to be essentially followed in order to increase the productivity of tuber crops. The role of plant growth substances in the physiology of plant is one of the most interesting chapters in the science. 
The plant growth substances are organic compounds, other than nutrients which in small concentration influence the physiological processes of plants.

Growth regulators are also reported to improve yield of many horticultural crops those in which the underground part is economically important.

\section{Effect of plant growth regulators on} vegetative and root tuber yield characters

Abdul Vahab and Mohana Kumaran (1980) reported that highest increase of sweet potato yield obtained with Ethrel (Ethephon) at 450 ppm and $300 \mathrm{ppm}$ whereas tuber girth was increased with CCC applied at higher concentrations of 500 and $1000 \mathrm{ppm}$

Baijal et al., (1983) reported that foliar application of $100 \mathrm{ppm} \mathrm{GA}_{3}$ at 20 days after transplanting significantly increased the plant height, inter nodal length, stolon number, tuber number per plant, tuber fresh weight and dry weight of potato per plant.

Higher leaf area index values during the active tuber bulking period (40 to 70 DAP) of potato by foliar application at lower concentration of CCC (500 ppm) and $\mathrm{GA}_{3}$ (50 and $100 \mathrm{ppm}$ ), while $\mathrm{GA}_{3}$ at higher concentration increased the tuber yield in sweet potato (Banerjee and Das, 1984); in carrot (Maurya and Lal, 1987)

Mahabir Singh et al., (1989) observed that foliar spray of $\mathrm{GA}_{3}$ (30, 35 and $\left.45 \mathrm{ppm}\right)$ recorded maximum plant height, number of leaves per plant, leaf length, width of leaf and fresh weight of leaf in radish.

Mohamed Yassin and Anbu (1996) reported that root length, root girth and root weight were increased by foliar application of CCC at 1000 ppm in radish.

Pravin prakash et al., (2001) reported that higher values of growth parameters and tuber yield of potato were recorded with the application of CCC (1000 ppm).
Remison et al., (2002) conducted an experiment on ten cassava varieties with three growth regulators $\left(\mathrm{GA}_{3}, \mathrm{ABA}\right.$ and IAA) at 5 levels $(0$, $25,50,75$ and $100 \mathrm{ppm}$ ) to study growth and yield of cassava. They reported that growth regulators increased the tuber yield and dry matter production by foliar application of $\mathrm{GA}_{3}$ at $25 \mathrm{ppm}$.

Obasi and Atanu (2005) conducted a field experiments to study the effect of foliar application of growth regulators on growth, flowering and rhizome yield of ginger. Results revealed that leaf area (LA), leaf development rate (LDR), stem elongation rate (SER), vigour index (VI) and rhizome yield were increased with CCC and decreased with $\mathrm{GA}_{3}$ and ethrel. Application of CCC @ 250 ppm significantly improved rhizome yield by $36.4 \%$.

Jirali et al., (2008) reported that the fresh and dry rhizome yield, number of mother rhizomes and length and circumference of primary and secondary fingers were more by foliar application of CCC 500 ppm in ginger.

Seema Sarkar (2008) studied the effect of $\mathrm{GA}_{3}$, CCC and their interactions on yield of sweet potato. He concluded that spraying of $\mathrm{GA}_{3}$ and $\mathrm{CCC}$ influenced yield of sweet potato irrespective of concentrations.

Sengupta et al., (2008) conducted an experiment to study growth and yield patterns of Ginger Cv. Gorubathan with different growth regulators. They revealed that spraying with $\mathrm{GA}_{3}$ at $150 \mathrm{ppm}$ and Ethrel at $150 \mathrm{ppm}$ showed maximum plant height and maximum number of pseudostem whereas maximum number of leaves per plant (72.19), maximum leaf length $(29.69 \mathrm{~cm})$ and leaf breadth $(2.80 \mathrm{~cm})$ were recorded in plants treated with Ethrel at 100 ppm, $\mathrm{GA}_{3}$ at $150 \mathrm{ppm}$ and $\mathrm{CCC}$ at $200 \mathrm{ppm}$. Maximum yield was recorded in the treatment $\mathrm{GA}_{3}$ at $150 \mathrm{ppm}$.

Shedge et al., (2008) conducted a study on effect of foliar application of $\mathrm{MH}$ and $\mathrm{CCC}$ on growth and yield of sweet potato. They revealed 
that $\mathrm{CCC}$ at $500 \mathrm{ppm}$ resulted in highest yield (23.64 t/ha) followed by $\mathrm{MH}(1000 \mathrm{ppm})$ and CCC (250 ppm).

Usha et al., (2009) found that foliar application of CCC at $300 \mathrm{ppm}$ reduces shoot growth and leaf area index, while rhizome diameter, fresh weight were enhanced significantly in Rhubarb.

Patel et al., (2010a) conducted an experiment on influence of plant growth regulators and their application methods on yield and quality of onion. Growth regulators $\mathrm{GA}_{3}$ and NAA each @ 50, 100 and $150 \mathrm{mg} / \mathrm{l}$ were tried as root dipping, foliar spray as well as their combinations and compared with control. The application of $\mathrm{GA}_{3} @ 50 \mathrm{mg} / \mathrm{l}$ as root dipping + foliar spray significantly increased volume of bulb, equatorial and polar diameter of bulb as well as bulb yield, whereas average weight of bulb was significantly increased with $\mathrm{GA}_{3}$ @ $100 \mathrm{mg} / \mathrm{l}$ as root dipping + foliar spray.

Patel et al., (2010b) reported that application of $\mathrm{GA}_{3} @ 50 \mathrm{mg} / \mathrm{l}$ significantly increased plant height, leaf length and number of leaves per plant compared to control in onion.

Abbas (2011) reported that foliar application of $\mathrm{GA}_{3}$ decreases root fresh weight and root dry weight in carrot.

Ashok et al., (2012) conducted a study on effect of foliar application of plant growth regulators on potato variety Kufri pukhraj. They revealed that growth promoters like $\mathrm{GA}_{3}$ and IAA @ 50 ppm significantly increases the tuber quality parameters like dry matter content, specific gravity, tuber shape index, peel flesh ratio and sugar content.

Thondaiman Velayutham and Parthiban (2013) conducted a study on role of growth regulators and chemicals on growth, yield and quality traits of Ginger variety Rio-de-janerio. They reported that foliar spraying of CCC at $500 \mathrm{ppm}$ recorded highest yield per hectare.

El-Tohamy et al., (2015) conducted a study on effects of yeast extract and $\mathrm{GA}_{3}$ on water status, growth, productivity and quality of sweet potato grown in sandy soils. Results revealed that foliar application of $\mathrm{GA}_{3} @ 200$ ppm was significantly increases the vine length, number of branches per plant, plant fresh weight, root diameter, root length and yield per plant.

\section{Effect of plant growth regulators on flower characters}

Ricard et al., (1990) reported that sweet potato cultivars (Jewel, Shore Gold and Vardaman) responded differently to different growth regulator application for number of flowers produced, percentage capsule set and number of seeds produced. They observed that $\mathrm{GA}_{3}$ at 300 ppm and 2, 4-D at $15 \mathrm{ppm}$ significantly increased the number of flowers in cultivars $v i z$. , 'jewel' and 'shore gold'.

Shalaby et al., (1994) studied the effects of growth regulator treatments on the promotion of flowering and seed setting in 3 sweet potato cultivars (VNGBUAY, I59 and CN10 38-18). Plants were sprayed 60 days after transplanting with 2, 4-D (3.75, 7.50 and $15 \mathrm{ppm})$ and $\mathrm{GA}_{3}$ $(150,300,600$ and $1200 \mathrm{ppm})$. All growth regulator treatments resulted in earlier flowering and more flowers per plant than the control treatment in all cultivars. All growth regulator concentrations induced capsule and seed set in I59 and C10 38-18. Percentage capsule set was highest following treatment with 7.5 ppm 2, 4$\mathrm{D}$, while $\mathrm{GA}_{3} @ 1200 \mathrm{ppm}$ resulted in the highest number of seeds per plant. Plants treated with the lowest concentrations of 2, 4-D and $\mathrm{GA}_{3}$ produced the heaviest seeds.

Obasi and Atanu (2005) conducted field experiments to study the effect of foliar application of growth regulators on growth, flowering and rhizome yield of ginger. Results showed that $\mathrm{GA}_{3}$ inhibited flowering and shoot emergence while ethrel had no effect on flowering but enhanced shoot emergence.

El-Gizawy et al., (2006) conducted a study on effect of $\mathrm{GA}_{3}$ on enhancing flowering and fruit setting in selected potato cultivars (Cara, 
Diamant and Spunta). They found that cara cultivar recorded the best response to $\mathrm{GA}_{3}$ with good flowering and fruit setting, followed by Cv. Spunta with good flowering but without fruit setting and $\mathrm{Cv}$. Diamant did not flower under any treatment.

Walter et al., (2013) conducted an experiment with 2, 4-D on sweet potato landraces. they reported that spraying of 2,4-D @ 100 ppm at 30 days after transplanting, initiated buds and set flowers after planting whereas 2,4-D applied at higher levels (300 and $500 \mathrm{ppm}$ ) results in extensive morphological and physiological disorders on plants.

\section{Effect of plant growth regulators on quality attributes of root tubers}

El-Gizawy et al., (2006) reported that foliar application of $\mathrm{GA}_{3}$ at 50 and 100 ppm significantly increases the total carbohydrate percentage in potato.

Seema Sarkar (2008) studied the effect of $\mathrm{GA}_{3}$, $\mathrm{CCC}$ and their interactions on reducing sugar and starch content of sweet potato. She concluded that $\mathrm{GA}_{3} @ 500$ ppm and CCC @ $1000 \mathrm{ppm}$ were the optimal concentrations for increasing the reducing sugars and starch content of the tubers.

From the present review, it is concluded that application of plant growth regulators in tuber crops has been found beneficial in improving growth, flowering, yield, quality attributes of root vegetables. In view of future thrust, awareness and popularizing among the farmers should be done to increase the area of growing vegetables by the application of plant growth substances.

\section{References}

Abbas, E.D. 2011. Effect of $\mathrm{GA}_{3}$ on growth and some physiological characters in carrot plant (Daucus carota L.). Ibn al-haitham Journal for pure and applied science. 24(3): 52-57.

Abdul Vahab, M. and Mohana Kumaran, N.
1980. National seminar on tuber crops production technology. Nov, Tamil Nadu Agricultural University (India). 137-141.

Ashok kumar, Singh, B.P and Hariom Katiyar. 2012. Effect of foliar application of plant growth regulators on potato tubers quality. Progressive Horticulture. 44(2): 299-303.

Baijal, B.D., Kumar, $\mathrm{P}$ and Alka Siddique, M.A. 1983. Interaction of growth regulators and photoperiods on growth flowering, stolon development tuber interaction and yield in potato. Indian Journal of Plant Physiology. 26(1): 6167.

Banerjee, N.C and Das, T.K. 1984. Effect of plant growth regulators on growth and tuber yield of potato. South Indian Horticulture. 32(2): 75-77.

El-Gizawy, A.M., Abou El-Yazied, A., Tawfik, A.A and El-Kaddour, A.A. 2006. Effect of gibberellic acid $\left(\mathrm{GA}_{3}\right)$ on enhancing flowering and fruit setting in selected potato cultivars. Annals of Agricultural Sciences. 51(1): 173-179.

El-Tohamy, W.A., El-Abagy, H.M., Badr, M.A., Abou-hussein, S.D., Helmy, Y.I and Shafeek, M.R. 2015. Effects of yeast extract and $\mathrm{GA}_{3}$ on water status, growth, productivity and quality of sweet potato grown in sandy soils. International Journal of Environment. 4(4): 256-261.

Jirali, D.I., Hiremath, S.M., Chetti, M.B and Patil, S.A. 2008. Studies on yield components, yield and quality attributes as affected by growth regulators in Turmeric. Journal of Eco-friendly Agriculture. 3(2): 119-122.

Mahabir Singh, Singh, R.P and Yadav, H.S. 1989. Response of growth regulators and their methods of application on yield of radish (Raphanus sativus L.). Bharatiya Krishi Anusandhana Patrika. 4(2): 84-88.

Maurya, C.P and Lal, S. 1987. Effect of IAA, NAA and GA on growth and yield of onion (Allium cepa L.). Bangladesh Horticulture. 15(3): 203-206.

Mohamed Yassin, G and Anbu, S. 1996. Effect of cycocel on growth and tuberisation of 
radish. (Raphanus sativus). South Indian Horticulture. 44(1\&2): 49-51.

Obasi, M.O and Atanu, S.O. 2005. Effect of growth regulators on growth, flowering and rhizome yield of ginger (Zingiber officinale Rosc). Nigerian Journal of Horticultural Science. 9(2): 69-73.

Patel, M.J., Patel, H.C and Chavda, J.C. 2010a. Influence of plant growth regulators and their application methods on yield and quality of onion (Allium cepa L.). The Asian Journal of Horticulture. 5(2): 263265.

Patel, M.J., Patel, H.C and Chavda, J.C. 2010b. Effect of plant growth regulators and their application methods on growth and yield of onion (Allium cepa L.) Cv. Gujarat white onion-1. Adv. Res. J. Crop Improv. 1(2): 85-87.

Pravin prakash, M.B., Chetti and Patil, S.S. 2001. Effect of plant growth regulators on growth parameters and yield of potato. Karnataka Journal of Agricultural Sciences. 14 (4): 938-942.

Remison, S.U., Ewanlen, D.O and Okaka, V.B. 2002. Evaluation of cassava varieties and effects of growth regulators on vegetative traits and yield. Tropical Agricultural Research and Extension. 5(2): 1-2.

Ricard, D., Lardizabal, Thompson, G and Paul. 1990. Growth regulators combined with grafting increase flower number and seed production in sweet Potato. Hortscience. 25(1):79-81.

Seema Sarkar, C.M. 2008. Interaction between $\mathrm{GA}_{3}$ and $\mathrm{CCC}$ on yield and quality of sweet potato International Journal of Plant Sciences. 3(2): 477-479.
Sengupta, D.K., Maity, T.K and Dasgupta, B. 2008. Effect of growth regulators on growth and rhizome production of ginger (Zingiber officinale Rosc.) in the hilly region of Darjeeling district. Journal of Crop and Weed. 4(2): 10-13.

Shalaby, G.I., Hussein, H.A., Farag, I.A., Badawy, A.S. 1994. Promotion of flowering and induction of seed setting in sweet potato (Ipomoea batatas (L.) Lam.). Asian Journal of Agricultural Sciences. 25 (3): 83-95.

Shedge, M.S., Khandekar, R.G and Bhagwat, N.R. 2008. Effect of foliar application of maleic hydrazide and cycocel on growth and yield of sweet potato. Journal of Root crops. 34(2): 120-128.

Thondaiman Velayutham, and Parthiban, S. 2013. Role of growth regulators and chemicals on growth, yield and quality traits of Ginger (Zingiber officinalis Rosc.). International Journal of Horticulture. 3(16): 91-95.

Usha, P., Rayirath, Rajasekaran, R., Lada, Claude, D., Caldwell, Samuel, K., Asiedu, Kevin, J., Sibley, Azure, D and Adams. 2009. CCC and Prohexadione-Ca enhance rhizome growth and lateral bud production in rhubarb (Rheum rhabarbarum L.). Journal of plant growth regulation. 28(2): 137-46.

Walter mutasa, Edmore gasura, Stanford mabasa, Ross tafadzwa masekesa and Dorren rudo masvodza. 2013. Does 2, 4dichlorophenoxy acetic acid induce flowering in sweet potato? African Journal of Biotechnology. 12(51): 70577062.

\section{How to cite this article:}

Koteswara Rao, G., M. Surendra Babu, M.M. Nagaraju, T. Thomson, G. Ranganna and Siva, M. 2017. A Critical Review on Effect of Plant Growth Regulators on Root Vegetables. Int.J.Curr.Microbiol.App.Sci. 6(7): 1243-1247. doi: https://doi.org/10.20546/ijcmas.2017.607.150 